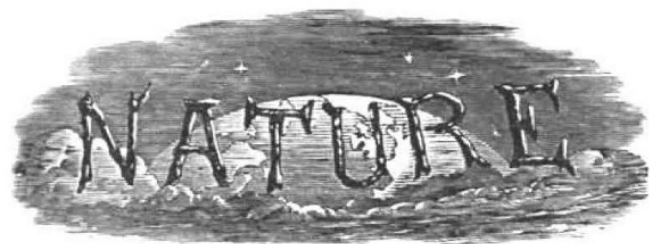

SATURDAY, SEPTEMBER 23, I922.

\section{CONTENT \.}

The Supply of Petroleum Products. By H. B. M. The Ways of Insects

Scientific Management of Fard

An Ideal Text-book of Physics. By N. R. C. ${ }^{\circ} 404$

Science Primers. By C. L. Bryant . . . . 406

Atmospheric Electricity. By G. Z. S. . . . 406

Forest Policy and Management. . . . . 407

Thoughts on Scientific Advance. By W. M. B. . 409

Our Bookshelf . . . . . . . . 409

Letters to the Editor:-

The Primitive Crust of the Earth.--John Parkinson 4I3

Action of Cutting Tools. -H. S. Rowell - -
The Smoke of Cities. - Prof. A. E. Boycott,

F.R.S., and Prof. J. B. Cohen, F.R.S. . $4^{1} 3$

Waterspouts. (Illustrated.) - Dr. G. D. Hale

Carpenter and D. Brunt . . . . . $4 \mathrm{I} 4$

Periodic Structure of Atoms and Elements. $-\mathbf{H}$. Newman Allen. $\dot{0}$. $\dot{\text { Sir }}$.

Transmission of Sound of Explosions.-Sir Napier Shaw, F.R.S. . • • . 415

Research and Razors.-Prof. J. R. Partington : 4I5

Human Geography: First Principles and some Applications. By Marion I. Newbigin, D.Sc. .

Educational and School Science. By Sir Richard Gregory

The Royal Botanic Gardens, Kew. (Illustrated) 423

Obituary :-

Dt, R. H. Codrington . . . . . . 425

Current Topics and Events . . . . . . . 426

Our Astronomical Column . . . . . . 428

Research Items . . . . . . . . 429

Potato Trials at Ormskirk . . . . . . . . 43I

International Reunion of Chemists at Utrecht. By

F. G. D. . · · • . . • .

Summary of the Theory of Relativity. By Prof.

H. T. H. Piaggio . . . . . . . 432

Kitchen Ranges. By J. B. C. . . . . . 434

University and Educational Intelligence. . . 435

Calendar of Industrial Pioneers . . . . . . 436

Societies and Academies . . . . . . . . $\quad .436$

Official Publications Received . . . . . $\quad$. 436

Editorial and Publishing Offices.

MALMILLAN \& CO., LTD.,

ST. MARTIN'S STREET, LONDON W C:2.

\begin{abstract}
Advertisements and business letters should be addressed to the Publishers.

Editorial communications to the Editor
\end{abstract}

Telegraphic Address: PHUSIS, LONDON.

Telephone Number: GERRARD 8830.

\section{The Supply of Petroleum Products.}

N R. SYDNEY BROOKS contributes to the 1 Fortnightly Review for September $\mathrm{x}$ an article entitled "A British Oil Victory," from which the reader might at first infer the discovery of a large British oilfield or at least a sudden remarkable flow from the Hardstoft well in Derbyshire. Nothing quite so startling has happened, however; Mr. Brooks's "victory" is of a far less sensational character, being, in fact, the opening of the Anglo-Persian Oil Company's refinery at Llandarcy, Swansea. The author regards this event as the pièce de résistance of a series of British achievements in the "international war of industry," and mentions in the same breath the opening of the Manchester Ship Canal Oil-Dock, the discovery of oil in Papua, and the securing by a British Company of the oil rights of Macedonia.

It seems a pity to have to disillusion Mr. Brooks and his readers, but while one admires his natural pride in British commercial successes, and also the patriotic zeal with which he writes; there is in his article an optimism apparently born of an inadequate knowledge of the facts and a clouded sense of proportion. The Llandarcy refinery is admittedly a sound industrial proposition for this country, but one can scarcely recognise yet in its existence a really serious competitor with the Shell or Anglo-American Oil Companies' interests, as Mr. Brooks suggests. Even if the AngloPersian Oil Company agreed to distribute their petroleum products solely in the British Isles, this would only represent a relatively small percentage of the total annual consumption of such commodities in this country. The bulk of imports of petroleum products come from the United States and Mexico; they are controlled by the Dutch and American organisations referred to and together constitute more than twenty. five times the amount of such products obtained from Persia, based on recent statistics of production and importation.

There is always the possibility - indeed, the probability - that the. Anglo-Persian Oil Company's interests will expand considerably in the next few years, but a refinery, however large and well-equipped, is dependent on an abundant. supply of crude oil, and this must come to us from overseas. So long as the United States and Mexico together produce more than 85 per cent of the world's supply of crude petroleum, so long shall we be dependent on those countries and their representatives for the bulk of our supplies of petroleum products.

The construction of the Llandarcy refinery is-indeed an: industrial eyent of no mean importance, but at least let us preserve a clear perspective in the matter. The

NO. 2760 , VOL. I IO] 
Manchester Ship Canal Oil Dock should be hailed rather as an engineering feat than an "oil victory"; without plenty of imported oil the dock ceases to exist as such. The strike of oil in Papua is not surprising; both in British and former German territory oil occurrences have long been known; geological surveys have been made and the oil sampled, but the technical difficulties, an appalling climate and the native labour troubles involved, have retarded development, even if oil exists in commercial quantity - yet a moot point. Then the Macedonian concessions are, geologically spenking, ever more doubtful than Papua as regards oil potentialities: their securance may have been a political or commercial coup, but as an incident in the "British Oil Victory," it was neither heroic nor decisive.

We suggest to Mr. Brooks that in the general appreciation of the above facts lies the reason of apparent public indifference to the erection of the Llandarcy refinery; the matter was neither ignored nor its significance missed, as he complains; it is simply that to the average man this and kindred propositions appeal as ordinary extensions to business, and where oil is concerned especially, judgment by results rather than hasty optimism at the beginning is the safer policy.

H. B. M.

\section{The Ways of Insects.}

The Psychic Life of Insects. By Prof. E. L. Bouvier. Translated by Dr. L. O. Howard. Pp. xvii +377 . (London: T. Fisher Unwin, Ltd., r922.) 8s. 6d. net. TH HIS is, we think, the most reasonable book that has been written on insect behaviour as a whole. It is scholarly and critical ; it avoids extremes ; and it leaves open questions open. There is, as every one recognises, an inclined plane of insect behaviour. On the lowest level there are tropistic activities (the translator's term " tropic" will not do), when the insect makes towards or away from the light, against the stream or the wind, towards or away from an odour, and so on. In everyday life these tropisms count for much. They are obligatory constitutional automatisms; they are induced by asymmetry of stimulus which provokes asymmetry of muscular activity ; and this automatically restores physiological equilibrium. Interesting situations arise when ane tropism (e.g. in relation to light) influences or counteracts another (e.g. in relation to gravity); and it is alsa noteworthy that a tropism may change its character with the age or physiological state of the organism.

Then we have to recognise internal rhythms hich are enregistered in the insect's constitution and imply a certain organic memory. Very suggestive is Roubaud's case of the African "house-worms" (maggots of Auchmeromyia luteola) which burrow in the earthen floor of the hut during the day, but come up at night to gorge themselves on the blood of the prostrate sleepers. For Roubaud has proved that these larva experimentally treated can be induced to remain awake during the day The rhythm is constitutional, but its punctuation is environmental.

Bouvier passes to the phenomena of "differential sensitiveness "- a term which never strikes us as very huminous. When a bed-bug, which naturally seeks darkness, is suddenly illumined, its typical behaviour is to turn through 180 degrees and proceed in the opposite direction. Insects avoid situations or postures which are contradictory to the exercise of their normal tropisms; but their behaviour is automatic, not voluntary. Moreover, the reversal of the movement in relation to a particular stimulus, șay light, may be induced by a sudden change in some other stimulation, e.g. by a gust of wind or a warm breath. The familiar phenomena of "catalepsy" or " feigning death " in insects are regarded as exaggerations of "differential sensitiveness," and the author is very sceptical as to utilitarian interpretations.

So far there is no appreciable psychical note. That is not struck till we find the insect selecting one reaction rather than another; profiting by experience in a simple way, and showing individual as contrasted with organic memory. Some very interesting examples are given of an individual change of habit in novel circumstances. The intelligent adjustment of habits has played an important part in the evolution of instinctive behaviour, for insects have "the power very quickly to transform acts which are intelligent at first into automatic acts."

Bouvier's position in regard to instinctive behaviour is eclectic. There is no special faculty of "instinct," and the various forms of instinctive behaviour are not all on the same level nor of the same origin; some may have arisen as germinal mutations (which will be afterwards tested in everyday life), while others may have arisen in the course of intelligent apprenticeship. "In an intelligent way, new habits are established, which by heredity are added to the patrimony of instinct, modifying it and forming one of the essential elements of its evolution." "It is probable that all the higher instincts had originally this intellectual quality." And yet Bouvier agrees with Bergson that instinctive behaviour is on a different tack from intelligent behaviour; they help one another; they are both "opposites and complements."

It is likely enough that Bouvier is right in believing that instinctive behaviour is manifold, and that it may be established as an innate capacity in more than one

$$
\text { No. } 2760 \text {, vOL. [10] }
$$

